\title{
MOSCOW IN 1666: NEW JERUSALEM, THIRD ROME, THIRD APOSTASY
}

In this essay the author examines the disappearance from official Russian discourse of the idea of Muscovy as the New Israel. She suggests that it may partly be explained in relation to his opponents' accusations of blasphemy against Patriarch Nikon for naming his monastery on the River Istra as New Jerusalem. These accusations were made in the context of apocalyptic rumours about Nikon as the Antichrist, and about the imminent appearance of the Antichrist in Jerusalem in 1666. The decisions of the Church council of 16661667 - including its repudiation of the idea of the Third Rome - seemed to many Old Believers to confirm prophecies about 1666 as the date of a third and final apostasy from the true faith, after the Great Schism of 1054 and the Union of Brest of 1596. The ideas of the Third Rome and New Israel persisted among some Old Believers; but unlike the idea of the Third Rome, which was re-interpreted in the $19^{\text {th }}$ and $20^{\text {th }}$ centuries as evidence of Russian messianism and imperialism, the idea of the New Israel has been comparatively neglected.

Keywords: 1666; Moscow; New Jerusalem; New Israel; Third Rome; apocalypse; apostasy; Patriarch Nikon; Old Believers.

В данном очерке рассматривается исчезновение из официального российского дискурса идеи «Московское государство - Новый Израиль». Автор предполагает, что это исчезновение отчасти объясняется обвинениями в богохульстве, выдвинутыми против патриарха Никона, назвавшего свой монастырь на реке Истре Новым Иерусалимом. Его противники выдвинули эти обвинения в контексте эсхатологических слухов о Никоне-Антихристе и о предстоящем появлении Антихриста в Иерусалиме в 1666 г. По мнению многих старообрядцев, решения церковного собора 1666-1667 гг., в том числе отрицание идеи «Москва Третий Рим», подтвердили пророчества о 1666 г. как о дате третьего, последнего отступления от истинной веры после Великого раскола 1054 г. и Брестской церковной унии 1596 г. Идеи «Москва - Третий Рим» и «Россия - Новый Израиль» сохранялись в старообрядческой среде; но, в отличие от идеи «Москва - Третий Рим», которую интерпретировали по-новому в XIX и XX вв. как свидетельство российского мессианизма и империализма, идея «Россия - Новый Израиль» оказалась обделена вниманием ученых.

Ключев ые слов а: 1666 год; Москва; Новый Иерусалим; Новый Израиль; Третий Рим; апокалипсис; отступление; патриарх Никон; старообрядцы. 
The idea of Moscow as the 'Third Rome' has been one of the most striking and influential concepts in both Russian and Western historiography. Some scholars have linked it both with the notion that Muscovy had a special destiny in world history, and with the view that it had ambitions for imperial expansion that were inherited not only by the tsarist empire but also by the Soviet Union.

Soon after the break-up of the USSR, however, a number of American historians published works that downplayed the importance of the Third Rome concept in Muscovite history, and stressed that it had been abandoned by the state and by the official Church by the end of the $17^{\text {th }}$ century. Donald Ostrowski argued that there are very few references to the Third Rome idea in Russian sources of the $16^{\text {th }}$ century, and that the only official document that mentions it is the decree establishing the Moscow patriarchate in 1589. Ostrowski recognised that the notion appears in some other sources, including literary works, in the late $16^{\text {th }}$ century and in the $17^{\text {th }}$ century, but he stressed that these were all non-official documents, and that there is no evidence that the idea influenced government policy or action [Ostrowski, p. 218, 219-243, 246]. Shortly afterwards Marshall Poe, then a colleague of Ostrowski's at Harvard, published an article that not only restated Ostrowski's argument about the relative insignificance of the Third Rome doctrine in $16^{\text {th }}$ and $17^{\text {th }}$-century Muscovy, but also examined its rediscovery in the $19^{\text {th }}$ and $20^{\text {th }}$ centuries, when it was misinterpreted as evidence of Muscovite messianism and imperial ambition [Poe]. Daniel Rowland of the University of Kentucky also agreed with Ostrowski about the limited circulation and influence of the Third Rome theme in Muscovy, and proceeded to argue that the idea of Russia as the 'New Israel' was in fact more important than the Third Rome idea in the $16^{\text {th }}$ and $17^{\text {th }}$ centuries [Rowland]. Rowland's study of the development of the New Israel theme is a scholarly piece of work, but his article had a topical political agenda: he argued that the image of Moscow as the Third Rome had been used, particularly in the West, to create an image of Muscovy as not only Eastern and exotic, but also imperialistic, prefiguring later Soviet expansionism; the idea of New Israel, by contrast, linked Muscovite culture with that of other Christian peoples, in Western Europe and America, who also held a view of themselves as divinely chosen [Rowland, p. 591-592, 613-614]. At a time when many liberals, both in the East and in the West, were hoping that post-Soviet Russia would reclaim its place in what Mihail Gorbachev had described as the 'common European home', Rowland's stress on the New Israel image as evidence of 'a common Christian ideological heritage shared by both Russia and Western Europe' [Rowland, p. 592] had considerable contemporary resonance.

In this essay I propose to re-examine the notions of Muscovy as the Third Rome and as the New Israel, focussing not so much on their origins as on their disappearance from official discourse by the end of the $17^{\text {th }}$ century. I shall pay particular attention to the year 1666, which witnessed the opening of the Church council that confirmed the reforms initiated by Patriarch Nikon in 1652. The council of 1666-1667 influenced the status 
of the concepts both of the Third Rome and of the New Israel: it suppressed the 'Tale of the Novgorod White Cowl', which contained a version of the Third Rome theory; and it criticised Nikon for describing himself as ' $\mathrm{Pa}$ triarch of the New Jerusalem' 1666 was also the year in which many Christians believed that the Apocalypse would occur; opponents of the Church reforms subsequently identified it with a third apostasy (отступление) from the true Christian faith, following the schism between the Eastern and Western Churches in 1054, and the Union of Brest in 1596.

$$
* \quad * \quad *
$$

Daniel Rowland's argument about the importance of the New Israel image was based largely on the use of Biblical parallels in $16^{\text {th }}$ and $17^{\text {th }}$ century Muscovite literature and culture [Rowland, p. 595-612]. He argued that this provided evidence of a succession of four chosen peoples: Israel to the Roman Empire to Byzantium to Muscovy [Ibid, p. 591, 595]. There are, however, problems with this approach. Unlike the Third Rome concept, which provides a specific narrative of a translatio imperii from Rome to Constantinople to Moscow, the idea of Muscovy as the New Israel offers no evidence of a succession from Israel to Rome. It may therefore be seen as simply a metaphor, rather than a view of Russia as the successor to Rome and Byzantium in a series of chosen peoples that begins with Israel. Indeed, the very fact that so many other Christian peoples have compared themselves to the Israelites of the Old Testament may suggest that we are dealing here with an analogy or an allegory, rather than with a theory of succession.

Rowland's evidence of the importance of New Israel ideas in Muscovite was drawn from a number of sources. He stressed the significance of the coronation ceremony of Ivan IV, in which Metropolitan Makarij compared the tsar to King David, and himself to the Prophet Samuel [Ibid, p. 596-599]. He also noted that the term 'New Israel' is used by Ivan Timofeev in his Vremennik, and that 'New Israel', 'New Zion' and similar terms can be found in other literary works about the Time of Troubles [Ibid, p. 604-605]. A younger American historian, Isaiah Gruber, in a recent book about the Orthodox Church during the Time of Troubles, has also stressed the use of New Israel terminology in Muscovy, and provided a number of quotations from historical documents and literary works to illustrate his argument [Gruber, p. 22, 23-50, 86-87, 181-184]. ${ }^{1}$

As well as written texts, Rowland examined visual evidence of the New Israel theme in Muscovy. In relation to art, he focussed on the icon of the Blessed Host of the Heavenly Tsar, in which Moscow is depicted as the New Jerusalem to which Ivan IV leads his forces back from his victory over

\footnotetext{
${ }^{1}$ In fact Gruber's interpretation of the 'New Israel' theme goes further than Rowland's: he argues that the Russians saw themselves 'literally' as New Israel [Gruber, p. 34, 180] and identified themselves completely with the Jews [Ibid, p. 22, 23]. Unlike Rowland, Gruber sees the Muscovites' concept of Russia as New Israel as 'unique' among Christian societies, rather than as a common factor linking Muscovite culture with that of the West [Ibid, p. 183].
} 
Kazan. In architecture, the author drew particular attention to the Cathedral of the Intercession on the Moat (St Basil's), with its Jerusalem Chapel, which played an important role in the Palm Sunday ceremony [Rowland, p. 605-609]. ${ }^{2}$ His final example was Patriarch Nikon's New Jerusalem monastery on the River Istra [Ibid, p. 609-612]. ${ }^{3}$

An important piece of evidence for the New Israel theme - to which Rowland did not, however, refer - is the front matter (the preliminary pages) of the 1663 Bible published by the Moscow Printing House. The verso of the title page contains a set of heraldic verses (стихи на герб) addressed to Tsar Aleksei, which include the line, 'Thrive and rule, great tsar, in the new Israel' («Успевай и царствуй, великий царю в новом Израиле») [Franklin, p. 77-78]. The frontispiece is an elaborate woodcut, in which the central image is the Muscovite double-headed eagle, with a representation of Tsar Aleksei on horseback on its breast. Below the eagle is a map of Moscow. Above the eagle are inscribed two biblical quotations about King Solomon; and above the map there is another biblical quotation: 'the city of the great king' («Градъ царя великаго»). The frontispiece thus clearly identifies Tsar Aleksei with King Solomon, and Moscow with Jerusalem [Ibid, p. 75-76. The frontispiece is reproduced on p. 74].

Patriarch Nikon himself, while self-exiled from Moscow, criticised the inscriptions on the frontispiece for applying to Aleksei the quotations about Solomon which, according to Nikon, were in fact prophecies about Christ [Ibid, p. 89-90]. ${ }^{4}$ And although Nikon had himself built a New Jerusalem monastery, he criticised the identification of Moscow as Jerusalem in the frontispiece of the Bible, implying that this was blasphemous: 'And for those proud men who now have transgressed greatly, and, appropriating to themselves the honour and glory of God, have put under their own feet, under the feet of the horse and eagle... the city of the Great King... («И иже ныне гордии законопреступоваху зело, и Божию честь и славу преписующе на свою, и подписующе под ногами своима коня и орла... град царя великаго...») [The Replies, p. 565; Patriarch Nikon, p. 620].5

Nikon himself was criticised for blasphemous behaviour in relation to the naming of his monastery on the River Istra as 'New Jerusalem'. In 1663 he was accused by the boyar S. L. Streshnev of dishonouring the Holy

\footnotetext{
${ }^{2}$ On New Jerusalem and New Israel imagery in Muscovite architecture see also [Flier, 2006]. On the New Jerusalem imagery in the Palm Sunday ceremony, see [Flier, 1997; Успенский, с. 443-446, 455-456].

${ }^{3}$ Here, however, Rowland did not describe the controversy which surrounded the name of the monastery after Nikon's departure from the patriarchate, which I shall discuss below. He mentioned only the fact that Nikon had to defend the name of the monastery [Rowland, p. 612], without explaining the nature of the criticisms to which the patriarch was responding.

${ }^{4}$ This is consistent with Nikon's criticism of Aleksei at around the same time for blasphemously permitting the use of the term 'the earthly God' to describe the tsar [Живов, Успенский, с. 144], and may be seen as evidence of Nikon's broader critique of Aleksei, after 1658 , for usurping the privileges of the Church by claiming sacred status.

${ }^{5}$ Palmer's volume is an English translation of Nikon’s 'Refutation’ («Возражение») from a manuscript that once belonged to the Resurrection Monastery (Воскресенский монастырь); Tumins and Vernadsky publish the Russian text of a manuscript copy from the Onega Monastery of the Cross (Онежский Крестный монастырь).
} 
City by calling his monastery 'New Jerusalem', but in his Reply to Streshnev's Question the patriarch claimed that the tsar himself had approved the name [The Replies, p. xxviii, 67-68; Patriarch Nikon, p. 149-150]. ${ }^{6}$ Archpriest Avvakum also hinted at an element of blasphemy or sacrilege on Nikon's part. In a letter of 1665 to igumen Feoktist, Avvakum referred mockingly to the New Jerusalem monastery as Zion, and claimed that the abyss of Hell opened there [Памятники, с. 547]. Here the reference to Hell suggests that Avvakum was thinking of the New Jerusalem not so much as the historic city in the Holy Land, but rather as the heavenly New Jerusalem described in Revelation $(3: 12 ; 21: 2,10)$. Subsequently, at the Church council of 1666-1667, Nikon was charged with calling himself the Patriarch of New Jerusalem, in disrespect to the Patriarch of (old) Jerusalem - an accusation which Nikon did not explicitly deny [History of the Condemnation, p. XXXI, XXXVIII, 158, 430].

Why was Nikon's use of the term New Jerusalem subjected to accusations of blasphemy or sacrilege in the 1660s, when references to Moscow as Jerusalem and Russia as Israel had been perfectly acceptable in previous years? For example, when Boris Godunov had embarked on a project to build a church in the Moscow Kremlin that was to be based both on the Temple of Solomon and on the church of the Holy Sepulchre in Jerusalem, ${ }^{7}$ the deacon Ivan Timofeev criticised him for his vanity [Rowland, p. 605, 608-609; Успенский, c. 443-444, 455-456], but Timofeev's criticism of Boris was slight compared with the criticisms of Nikon for his similar project, implemented half a century later. Viktor Zhivov and Boris Uspenskij have suggested that in the context of the sacralisation of the monarch in the mid-17 $7^{\text {th }}$ century some terms and formulas that had previously been acceptable might now be regarded as blasphemous by traditionalists [Живов, Успенский, с. 127-128, 133-136]. Zhivov and Uspenskij's main example is the designation of the tsar as 'holy' but comparisons of Russia with Israel (the Holy Land) and Moscow with Jerusalem (the Holy City) might also have been seen as sacrilegious at that time. Thus the increased sensitivity of the Muscovite authorities to symptoms of the sacralisation of the monarch, in the light of the hostility of traditional believers towards it, may have contributed to a decline in the usage of the concept of the New Israel in the late $17^{\text {th }}$ century.

Even more significant - and more sinister - than the accusations of blasphemy were suggestions that Nikon's naming of his monastery reflected his association with the Antichrist. Paisius Ligarides, the Metropolitan of Gaza, insinuated in one of his Answers to Streshnev's Questions that, since the Jews believed that a new Messiah would come from a new Jerusalem, the mother of the Antichrist might be found with Nikon in his New Jerusalem monastery [The Replies, p. xxviii, 68; Patriarch Nikon, p. 150]. Nikon in his Reply retorted that other authorities stated that the Antichrist would be

\footnotetext{
${ }^{6}$ For a further defence by Nikon of his use of the name 'New Jerusalem', see also [The Replies, p. 78-83; Patriarch Nikon, p. 158-163].

The project was incomplete at the time of Boris' death, and the unfinished structure was destroyed by his successors.
} 
born in the original Jerusalem, and that it was therefore absurd to claim that he would appear in the New Jerusalem monastery [The Replies, p. 68-78; Patriarch Nikon, p. 150-158]. ${ }^{8}$ The association of Nikon with the Antichrist because he had named his monastery New Jerusalem was also made by some of his Russian opponents. Before 1666, rumours in the Soloveczkij monastery that Nikon was the Antichrist alluded to his building of the church of the Resurrection at the New Jerusalem monastery. The rumours were somewhat confused and obscure, but O. V. Chumicheva interprets them to mean that Nikon was seen as the Antichrist partly because he had tried to build New Jerusalem on earth [Чумичева, c. 56-57, 161-162, 261]. ${ }^{9}$

Why did the criticisms of Nikon for building a New Jerusalem monastery associate him with the Antichrist? The answer may lie in the fact that, by the middle of the $17^{\text {th }}$ century, apocalyptic ideas of the imminence of the Last Judgment and the appearance of the Antichrist had become widespread in Muscovy. In $15^{\text {th }}$-century Russia, the Apocalypse had been expected in 1492, at the end of the seventh millennium from the creation of the world (in 5508 B. C.). When the world did not end on that date, various alternative calculations were made, pointing to the years 7070 (1562 A. D.) or 7077 (1569). These revised dates have led the historian Andrei Yurganov to speculate that the behaviour of Ivan IV at the time of the oprichnina (1565-1572) might be associated with the tsar's expectation of the imminent Apocalypse [Юрганов]. In the $17^{\text {th }}$ century, Muscovite ideas about the Apocalypse were largely derived from the Book of Faith («Книга о вере»), which was published in Moscow in 1648, and based on the Palinodiya of the Kievan theologian Zahariya Kopy'stenskij, written in the 1620s. Kopy'stenskij's dating of the Apocalypse combined the Biblical concepts of the millennium (Rev. 20:1-8) with the number of the beast, to give an end date of $1666(1000+666)$, and the Book of Faith also accepted 1666 as the date of the Apocalypse [Опарина, с. 290-296]. ${ }^{10}$ Thus the association of Nikon with the Antichrist, who was expected to appear in Jerusalem in 1666, may help to explain some of the criticisms of his naming of his monastery as New Jerusalem that were made in the 1660s.

By the end of the $17^{\text {th }}$ century the identification of Russia as the New Israel was in full retreat. The New Jerusalem monastery remained standing, of course, and the 1663 Bible, with its reference to the 'New Israel', was not superseded until 1751 [Franklin, p. 92]. In 1697, however, Peter the

\footnotetext{
${ }^{8}$ The references to Jerusalem in connection to the appearance of the Antichrist appear to be based on 2 Thessalonians 2:1-5, which states that before Christ's second coming the 'man of lawlessness' will be revealed in the 'temple of God'.

${ }^{9}$ The Soloveczkij monk Ioakim also calculated that according to an alphabetic system of numerology Nikon's name (originally Nikita, or Nikitios in Greek) could be represented as 666, the number of the beast in Revelation (13:18) that was conventionally associated with the Antichrist [Чумичева, c. 56, 161-162, 261].

${ }^{10}$ The year 1666 was also predicted as the date of the Apocalypse by some Christians in Western Europe, especially in England at the time of the Civil War of the mid-1 $17^{\text {th }}$ century. It was also rumoured that Sabbatai Zevi, the false Jewish Messiah, would appear in Jerusalem in 1666. Paisius Ligarides's reference to the new Messiah whom the Jews were expecting in the new Jerusalem (see above) may have been a reference to Sabbatai Zevi.
} 
Great abolished the Palm Sunday ritual in Moscow, with its re-enactment of Christ's entry into Jerusalem [Живов, Успенский, с. 168]; and the removal of the capital to St Petersburg in the early $18^{\text {th }}$ century meant the abandonment by the court of the sacred spaces in Moscow (such as the Jerusalem chapel of St Basil's Cathedral) that were associated with the idea of the New Israel.

By this time, the idea of Moscow the Third Rome had also been abandoned by the official Orthodox Church. The Church council of 1666-1667 effectively rejected the idea of Moscow as the Third Rome, when it banned the 'Tale of the Novgorodian White Cowl', a literary work which includes a version of the story of the succession of the true faith from early Christian Rome to Constantinople to 'the Rus' land'. According to the 'Third Rome' analysis, the Greek Orthodox Church of Constantinople had fallen into error in the $15^{\text {th }}$ century, and the role of protector of the true faith had passed to Moscow. The Church reforms that were approved by the council of 16661667, however, implied that the Greek Church retained the true faith to a greater extent than the Russian Church, whose service books were riddled with errors and in need of correction on the Greek model [Зеньковский, c. 301-302]. Thereafter, the concept of the Third Rome disappeared from official Russian discourse. Peter the Great revived the idea of a succession from Rome to Moscow, but without the intermediate stage of Constantinople: he harked back to Imperial Rome when he assumed the title of imperator, and named his new capital as the City of St Peter.

For the Old Believers, the decisions of the Church council of 1666-1667 confirmed the prophecy in the Book of Faith about 1666 as the date of the third and last apostasy. Zahariya Kopy囚stenskij had provided a schema of a series of four apostasies from the true faith, beginning with the Great Schism in the Church (which he dated in round numbers to 1000 A. D.) followed by the Union of Brest (1596, rounded up to 1600), and predicting similar future events in 1660 and 1666 [Опарина, с. 291-292]. The Book of Faith, however, provided a threefold sequence, 1000-1600-1666; and the outcome of the Church council of 1666-1667, which declared the opponents of the Church reforms anathema, meant that the Old Believers preferred that threefold series, not only because the events of 1666 in Russia seemed to confirm the prophecy, but perhaps also - as Tat囚yana Oparina has suggested [Ibid, c. 308] - because the threefold formula tallied with the existing Muscovite concept of the Third Rome. ${ }^{11}$ But whereas in the Muscovite 'Third Rome' formula the sequence of lands of the true faith passed from Rome to Constantinople to Russia, the Old Believers' succession of three apostasies moved from Rome to Muscovy via Kiev. The fall of Constantinople was thus omitted, since the formula of the series of apostasies had been borrowed from the Orthodox lands of the Polish-Lithuanian

${ }^{11}$ The Old Believer Deacon Fedor, in his letter to Ioann Avvakumovich, wrote, echoing Filofej's formula that there would never be a Fourth Rome, 'Nowhere will there be another apostasy: ...the last Rus' is here’ («Иного отступления уже нигде не будет... последняя Русь здъ») [quoted in Опарина, с. 307]. 
Commonwealth, where the idea of the Third Rome had never been current [Опарина, с. 308].

The world did not end in 1666, of course, nor had it ended by 1670 (an alternative end date, if due adjustment were made for the belief that the Antichrist would reign for three and a half years). For many Old Believers, the events of 1666-1667 meant that the Antichrist was already in their midst, and some of them responded with self-immolation. Others re-calculated the date of the Apocalypse to 1692 (7200 years from the Creation) [Зеньковский, c. 445-446]. In 1687, for example, the Old Believer Kuz'ma Kosoj declared on the Don that 'only five years of our existence remain' («житья де нашего только пять лет») [Дружинин, с. 268]; his associate Kuz'ma Sidorov also claimed that Christ's second coming would be in five years' time, justifying this with some complex calculations involving the apostasy of Rome and other western lands in 1000 A.D., the date 1595, the number 666, and the apostasy of the Muscovite tsardom from the Orthodox faith under 'Nikon the blood-letter' (кровопроливец) [Ibid, c. 271].

Some of the Old Believers on the Don, however, while holding to the idea that the final apostasy had taken place in Moscow in 1666, believed that the true faith still survived in their own midst, and might flourish again. For example, the Old Believer Samojla Larionov abused a Nikonian priest in 1687, saying, 'You are of the apostate faith and the new law; you have come from the Antichrist. Rome, the Poles, and Kiev and its allies, and the Greeks and Moscow have fallen away; nowhere is there any piety; only a small branch has remained on our dear River Don, and from that branch much piety will grow!' («Ты отпадшей веры и новаго закону; приехал от антихриста. Рим, Поляки и Киев с товарищи и Греки и Москва отпали; нет нигде благочестия; только малая ветвь осталась на Дону Ивановиче, и от ветви многое благочестие процветет!») [Ibid, c. 139].

For some Old Believers, the piety that survived in their midst was identified with the Third Rome and the New Israel, but in both cases these concepts now related to the Russian people, rather than to the state. As early as the 1670s, Archpriest Avvakum referred to 'the Russian people - the last seed of Abraham remaining on the earth, that is, the New Israel' («росийский народ - последнее, оставшее на земли семя Авраамле, то есть: Новый Израиль») [Русская, стб. 328]. ${ }^{12}$ And at the beginning of the $18^{\text {th }}$ century, the Denisov brothers of the Vyg community of Old Believers argued that even though the official Church and state had gone over to the Antichrist the true faith survived in local communities, among the ordinary Russian people. The Denisovs thus provided what Sergej Zen'kovskij has described as an 'ideological democratisation' (идеологическая демократизация) of the Third Rome idea, identifying it with the nation, not the state [Зеньковский, c. 461; see also Zenkovsky, p. 57-60]. More recently, the respected British historian Geoffrey Hosking, following Zen'kovskij, has argued that the messianic idea of the Third Rome was preserved and democratised by the Old

\footnotetext{
${ }^{12}$ For further references to the ideas of the Third Rome and the New Israel idea among Old Believers in the late $17^{\text {th }}$ century, see [Лукин, с. 188-195].
} 
Believers. In a number of his works, Hosking cites with approval the historian of Old Belief, V. I. Kel'siev, who wrote in his 'Confession' («Исповедь») that the peasantry in the mid- $19^{\text {th }}$ century continued to believe that Moscow was the Third Rome and that Russia was the New Israel [Hosking, 1997a, p. 209; Hosking, 1997b, p. 73; Hosking, 2001, p. 174; Hosking, 2006, p. 22]. To a certain extent, Hosking is here reviving one of the ideas of the émigré Russian philosopher Nicolas Berdyaev, who argued that, after the schism of the $17^{\text {th }}$ century, messianic ideas such as the Third Rome were preserved not only among the Old Believers but also among the Russian people as a whole, where they later provided a fertile breeding ground for the Communist messianism of the intelligentsia that was to turn the monk Filofei's Third Rome into Lenin's Third International [Berdyaev, p. 2-5, 38-39, 41, 71-73]. ${ }^{13}$

$$
* * *
$$

Thus while Daniel Rowland was undoubtedly correct when he claimed that the idea of Muscovy as the New Israel was at least as important in $16^{\text {th }}$ and $17^{\text {th }}$-century Russian thought as the idea of 'Moscow, the Third Rome', the American historian has told only part of the story. It was not only the idea of the Third Rome that had been 'discarded by everyone except the Old Believers' by 1700 [Rowland, p. 594]. The idea of Russia as the New Israel was also in retreat by that date, having been censured by opponents of the sacralisation of the monarch, and discredited by the criticisms of Nikon's New Jerusalem monastery that were made in the context of apocalyptic rumours about Nikon as the Antichrist, and about the imminent appearance of the Antichrist in 1666 in Jerusalem. The Church council of 1666-1667 condemned the idea of the Third Rome, and many Old Believers saw this as confirmation of the prophecy that a final apostasy would take place in 1666. Some Old Believers identified the true faith that survived in their own midst with the Third Rome, and with the New Jerusalem. But although the concept of the Third Rome was rediscovered by the Russian intelligentsia in the $19^{\text {th }}$ century, when it was given an imperialistic significance that it had not had in Muscovy, the idea of the New Israel underwent no such revival in educated Russian society.

Дружинин В. Г. Раскол на Дону в конце XVII века. СПб, 1889.

Живов В. М., Успенский Б. А. Царь и Бог: Семиотические аспекты сакрализации монарха в России // Успенский Б. А. Избранные труды. Т. 1: Семиотика истории. Семиотика культуры. М. : Гнозис, 1994. С. 110-218.

Зеньковский C. Русское старообрядчество. Духовные движения семнадцатого века = Zenkovsky S. A. Russia's Old-Believers. Spiritual movements of the seventeenth century. Мюнхен, 1970.

Лукин П. В. Народные представления о царской власти в России XVII века. М. : Наука, 2000. 298 с. p. 7-8].

${ }^{13}$ Hosking acknowledges the influence of Berdyaev on his ideas [see Hosking, 2006, 
Onарина T. A. Число 1666 в русскойкнижностисередины-третьейчетверти XVIIв.// Человек между Царством и Империей: сб. материалов междунар. конф. / под ред. М. С. Киселевой. М. : Ин-т человека РАН, 2003. С. 287-318.

Памятники литературы Древней Руси: XVII век. Книга первая. М. : Художественная литература, 1988.

Русская историческая библиотека. Т. 39: Памятники истории старообрядчества XVII в. Л. : Изд-во АН СССР, 1927. 590 с.

Успенский Б. А. Царь и патриарх: харизма власти в России (Византийская модель и ее русское переосмысление). М. : Языки русской культуры, 1998. 680 с.

Чумичева О. В. Соловецкое восстание 1667-1676 гг. 2-е изд. М. : ОГИ, 2009. 352 с.

Юрганов А. Л. Опричнина и страшный суд // Отечественная история. 1997. № 3.

C. $52-75$.

Berdyaev N. The Russian Revolution. Ann Arbor : University of Michigan Press, 1961 (first published 1931).

Flier M. S. Court ceremony in an age of reform. Patriarch Nikon and the Palm Sunday ritual // Religion and culture in early modern Russia and Ukraine / ed. by S. H. Baron, N. Sh. Kollmann. DeKalb : Northern Illinois University Press, 1997. P. 73-95.

Flier M. S. Political ideas and rituals // The Cambridge History of Russia. Vol. 1: From early Rus' to 1689 / ed. by M. Perrie. Cambridge : Cambridge University Press, 2006. P. $387-408$.

Franklin S. Printing Moscow: Significances of the frontispiece to the 1663 Bible // The Slavonic and East European Review. 2010. Vol. 88. No. 1-2 (Jan.-April). P. 73-95.

Gruber I. Orthodox Russia in crisis: Church and nation in the Time of Troubles. DeKalb : Northern Illinois University Press, 2012.

History of the Condemnation of the Patriarch Nicon by a Plenary Council of the Orthodox Catholic Eastern Church, held at Moscow A. D. 1666-1667, written by Paisius Ligarides of Scio Ligarides / transl. by W. Palmer. London : Trübner, 1873.

Hosking $G$. The Russian national myth repudiated // Myths and nationhood / ed. by G. Hosking, G. Schöpflin. London : Hurst \& Company, 1997a. P. 198-210.

Hosking G. Russia: People and Empire, 1552-1917. London, 1997 b.

Hosking G. Russia and the Russians: A history. London, 2001.

Hosking $G$. Rulers and victims. The Russians in the Soviet Union. Cambridge, MA ; London : Harvard University Press, 2006.

Ostrowski D. Muscovy and the Mongols: cross-cultural influences on the steppe frontier, 1304-1589. Cambridge : Cambridge University Press, 1998.

Patriarch Nikon on Church and State: Nikon's "Refutation" / ed. by V. A. Tumins, G. Vernadsky. Berlin, New York, Amsterdam : Mouton, 1982.

Poe M. Moscow, the Third Rome: the origins and transformations of a "pivotal moment" // Jahrbücher für Geschichte Osteuropas. 2001. Band 49. Heft 3. S. 412-429.

Rowland D. B. Moscow - the Third Rome or the New Israel? // The Russian Review. 1996. Vol. 55. P. 591-614.

The Replies of the humble Nicon, by the mercy of God Patriarch, against the Questions of the boyar Simeon Streshneff and the Answers of the Metropolitan of Gaza Paisius Ligarides / transl. by W. Palmer. London : Trübner, 1871.

Zenkovsky S. A. The ideological world of the Denisov brothers // Harvard Slavic Studies. 1957. Vol. 3. P. 49-66. Press.

Berdyaev, N. (1961). The Russian Revolution. Ann Arbor: University of Michigan

Chumicheva, O. V. (2009). Soloveczkoe vosstanie 1667-1676 gg. [Solovetsky rebellion in 1667-1676 yrs.]. (2 $2^{\text {nd }}$ ed.). Moscow: OGI.

Druzhinin, V. G. (1889). Raskol na Donu v konce XVII veka [Split on the Don in the late $17^{\text {th }}$ century]. St. Petersburg.

Flier, M. S. (1997). Court ceremony in an age of reform. Patriarch Nikon and the Palm Sunday ritual. In S. H. Baron \& N. Sh. Kollmann (Eds.), Religion and culture in early modern Russia and Ukraine (pp. 73-95). DeKalb: Northern Illinois University Press.

Flier, M. S. (2006). Political ideas and rituals. In M. Perrie (Ed.), The Cambridge History of Russia. Vol.1: From early Rus' to 1689 (pp. 387-408). Cambridge: Cambridge University Press. 
Franklin, S. (2010). Printing Moscow: Significances of the frontispiece to the 1663 Bible. The Slavonic and East European Review, 88, 1-2 (Jan.-April), 73-95.

Gruber, I. (2012). Orthodox Russia in crisis: Church and nation in the Time of Troubles. DeKalb: Northern Illinois University Press.

Hosking, G. (1997). Russia: People and Empire, 1552-1917. London.

Hosking, G. (1997). The Russian national myth repudiated. In G. Hosking \& G. Schöpflin (Eds.), Myths and nationhood (pp. 198-210). London: Hurst \& Company.

Hosking, G. (2001). Russia and the Russians: A history. London.

Hosking, G. (2006). Rulers and victims. The Russians in the Soviet Union. Cambridge, MA \& London: Harvard University Press.

Lukin, P. V. (2000). Narodny'e predstavleniya o czarskoj vlasti v Rossii XVII veka [People's ideas on the throne in Russia in $17^{\text {th }}$ century]. Moscow: Nauka.

Oparina, T. A. (2003). Chislo 1666 v russkoj knizhnosti serediny' - tret'ej chetverti XVII v. [Number 1666 in Russian book-learning in the middle-third quarter of $17^{\text {th }} \mathrm{c}$.] In M. S. Kiseleva (Ed.), Chelovek mezhdu Czarstvom i Imperiej: sbornik materialov mezhdunarodnoj konferencii (pp. 287-318). Moscow: Institut cheloveka RAN.

Ostrowski, D. (1998). Muscovy and the Mongols: cross-cultural influences on the steppe frontier, 1304-1589. Cambridge: Cambridge University Press.

Palmer, W. (Transl.). (1871). The Replies of the humble Nicon, by the mercy of God Patriarch, against the Questions of the boyar Simeon Streshneff and the Answers of the Metropolitan of Gaza Paisius Ligarides. London: Trübner.

Palmer, W. (Transl.). (1873). History of the Condemnation of the Patriarch Nicon by a Plenary Council of the Orthodox Catholic Eastern Church, held at Moscow A. D. 16661667, written by Paisius Ligarides of Scio Ligarides. London: Trübner.

Pamyatniki literatury' Drevnej Rusi: XVII vek. Kniga pervaya [Litarary works of the Old Russia: $17^{\text {th }}$ century. Book one]. (1988). Moscow: Hudozhestvennaya literatura.

Poe, M. (2001). Moscow, the Third Rome: the origins and transformations of a "pivotal moment". Jahrbücher für Geschichte Osteuropas, 49, 3, 412-429.

Rowland, D. B. (1996). Moscow - the Third Rome or the New Israel? In The Russian Review. (Vol. 55, pp. 591-614).

Russkaya istoricheskaya biblioteka. T. 39: Pamyatniki istorii staroobryadchestva XVIIv. [Russian historical library. Vol. 39: Monuments of the Old Belief history of $17^{\text {th }}$ c.]. (1927). Leningrad: Izdatelstvo AN SSSR.

Tumins, V. A. \& Vernadsky, G. (Eds.). (1982). Patriarch Nikon on Church and State: Nikon's "Refutation". Berlin, New York, Amsterdam: Mouton.

Uspenskij, B. A. (1998). Czar' i patriarch: harizma vlasti v Rossii (Vizantijskaya model' i ee russkoe pereosmy'slenie) [Tsar and patriarch: charisma of power in Russia (Byzantine model and its Russian rethinking)]. Moscow: Yazy'ki russkoj kul'tury'.

Yurganov, A. L. (1997). Oprichnina i strashny'j sud [Oprichnina and the Day of Judgement]. Otechestvennaya istoriya, 3, 52-75.

Zenkovsky, S. A. (1957). The ideological world of the Denisov brothers. In Harvard Slavic Studies. (Vol. 3, pp. 49-66).

Zenkovsky, S. A. (1970). Russkoe staroobryadchestvo. Duhovny'e dvizheniya semnadczatogo veka [Old-Belief in Russia. Spiritual movements of the seventeenth century]. Munich.

Zhivov, V. M. \& Uspenskij, B. A. (1994). Czar' i Bog: Semioticheskie aspekty' sakralizacii monarha v Rossii [Tsar and God: semiotic aspects of the sacralisation of the monarch in Russia]. In B. A. Uspenskij Izbranny'e trudy'. T. 1: Semiotika istorii. Semiotika kul'tury' (Vol. 1, pp. 110-218). Moscow: Gnozis.

The article was submitted on 18.04.2014

\section{Морин Перри}

профессор

Великобритания, Университет Бирмингема

m.p.perrie@bham.ac.uk

\author{
Maureen Perrie \\ Professor \\ UK, University of Birmingham \\ m.p.perrie@bham.ac.uk
}

